УАK 323(470+571)

ББК66.3(2Poc)

DOI 10.22394/1682-2358-2021-2-104-114

N.D. Shikber, post-graduate student of the National and Federal Relations Department, Russian Presidential Academy of National Economy and Public Administration, Head of the Political Rights Protection Department of the Office of the Ombudsman for Human Rights in the Russian Federation

\section{STATE-CONFESSIONAL RELATIONS MODERN CLASSIFICATIONS ANALYSIS}

The typologies of relations between the state and religious associations existing in the scientific doctrine, are considered. Based on a systematic analysis, the typologies are grouped according to the complexity of the internal structure and analyzed for universality of application. The author has proposed a new classification of state-confessional relations models which most fully reflects the realities of the modern world.

Key words and word-combinations: state-confessional relations, religious associations, religion in the state.
H.A. Шихер, аспирант кафедри начиональньгх и федеративньгх отношений Российской академии народного хозяйства и государственной служби при Президенте РФ, начальник отдела зашить политически прав Аппарата Уполномоченного по правам человека в Российской Федераuиu (email: Raspberry33@yandex.ru)

\section{АНААИЗ СОВРЕМЕННЫХ КААССИФИКАЦИЙ ГОСУААРСТВЕННО- КОНФЕССИОНААЬНЫХ ОТНОШЕНИЙ}

\begin{abstract}
Аннотацияя. Рассмотрены существующие в научной доктрине типологии взаимоотношений государства с религиозными объединениями. На основе системного анализа типологии сгруппированы по принципу сложности внутренней структуры и проанализированы на предмет универсальности применения. Автором предложена новая классификация моделей государственноконфессиональных отношений, наиболее полно отражающая реалии современного мира.

Ключевые слова и словосочетания: государственно-конфессиональные отношения, религиозные объединения, религия в государстве.

B научной митературе не прекращаются попытки создания кмассификаций государственно-конфессиональных отношений со стороны представителей самых различных сфер деятельности - юристов, религиовеАов, политологов, социологов, историков, - что влечет необходимость более глубокого критического анализа.
\end{abstract}


Попытаемся упорядочить данные классификации, провести их сравнительный анализ, выявить самую оптимальную и эффективную из них мибо предложить собственную. Рассмотрим предлагаемые в научной доктрине классификации государственно-конфессиональных отношений по принципу - от простых к сложным, от дихотомических - к многосоставным.

Самой ранней типологией считается конџепџия Франческо Руффини, сформулированная в начале XX столетия. Автор подразделяет государства на две группы: с режимом «сепаратизма» (формальное юридическое равенство по отношению ко всем религиозным объединениям) и с режимом «юрисдикционизма» (режим пропорционального благоприятствования в отношении к каждой из существуюших церквей). Последователем Ф. Руффини является М. Вебер [1, с. 9], который модель с режимом благоприятствования дифференцирует на иерократию (обожкествление власти священством), теократию (правовое закрепление власти духовенства) и цезаропапизм (становмение во главе церкви светского правителя).

Современные Аихотомические кмассификации по сути повторяют концепцию Ф. Руффини, в соответствии с которыми преАлагается к первой модели взаимоотношений отнести такую, где религиозные объединения от государства отделены, а ко второй - где действует тот или иной режим благоприятствования в отношении религиозных объединений. К таковым могут быть отнесены типологии Н.В. Володиной [2, с. 64], М.И. ОАинцова [3, с. 36] и С.В. Потаниной [4, с. 108-111], именующих два выдемяемых типа государства светскими и конфессиональными. С.В. Ажораева классифиџирует их на модели с симфонией (союзом между государством и церковью, как это было Византийской империи) и модели, где церковь сушествует независимо от светских вмастей [5, с. 37-45]. $\Lambda$.А. Морозова выделяет тип государства с государственной церковью, признанной доминирующей, и тип, где церковь от государства отделена, и всем религиозным объединениям предоставлены равные права [6, с. 92] .

Следуя аналогичной могике, А.В. Аогинов [7, с. 110-141] и О.Н. Четверикова [8, с. 18-33] подраздемяют государственно-конфессиональные отношения на модели - дифференцированную и универсальную. Универсальный тип характерен для стран, где церковь отделена от государства, а все религиозные объединения имеют одинаковый правовой статус (современные США, Франция, Нидерланды).

Аифференцированный тип включает в себя несколько подтипов: страны, где функционирует государственная церковь, привикегированная в своих правах, но полностью подконтрольная государству (Швеция, Ангмия, Норвегия, Греция, Аания, Исландия, некоторые мусульманские страны) [9, с. 76-81]; государства, где в сику исторического и соџиального положения выделяется традиџионная церковь, однако в целом действует принџип равенства религиозных объединений (Болгария, Аитва, Бельгия); государства, где заключены договоры (конкордаты) с одним или несколькими религиозными объединениями (Италия, Германия, Испания). По 
мнению итальянских правоведов С. Феррари [10, с .95] и Ф. Сильвио [11, с. 111] , конкордаты обеспечивают религиозным объединениям даже более серьезную правовую защиту, чем статус государственной церкви, поскольку их положения приравниваются к международно-правовым договорам без права изменения в одностороннем порядке. К примеру, Святым Престолом в настоящее время заключены 75 Авусторонних Аипломатических Аоговоров и 54 конкордата [12, с. 57-60].

Как отмечает А.В. Аогинов, в ряде случаев все три модели, относящиеся к Аифференцированному типу, могут сочетаться в одном государстве. Например, в Ирландии в силу конституционной нормы Римско-Католическая Церковь имеет государственный статус, а определенные традиџионные религиозные общины признаются государством [13, с. 38] .

На наш взгляА, Аихотомические классификации по-минималистски весьма УАобны, посколыку поА них можно подстроить практически мюбые государственно-конфессиональные отношения различных государств в разные периоды их сушествования, за исключением, пожалуй, азиатских стран. Вместе с тем эти классификации слишком просты и не отражают всей палитры государственно-конфессиональных отношений, имеюшейся в современном мире.

Следующая группа типологий государственно-конфессиональных отношений вкАючает в себя по три видовых категории.

Так, М.О. Шахов называет следующие типовые модели:

- сегрегаџионную (религия рассматривается государством как отрицательное соџиальное явление, которое следует минимизировать или вовсе истребить);

- сепарационную (нейтральность государства в отношении религии);

- кооперационную (государство взаимодействует с религиозными объединениями в соџиальной сфере) [14, с. 317] .

Схожую типологию, но с измененным названием и несколько расширенной интерпретацией одной из модемей, предмагает А.Ю. Григоренко:

- сегрегационная (в государстве исповедуется атеистическая идеология, все религиозные объединения находятся в притесненном положении и обречены на постепенное вымирание);

- сепаратистская (равенство всех религиозных объединений, невмешательство государства в процессы религиозной жизни);

- интегративная (государство поддерживает религиозные объединения, интегрируя их в общественную жизнь как офиџиально признаваемый институт). Внутри данной модели автор выделяет режимы: тоталитарный, авторитарный, соџиального партнерства [15, с. 107].

И.А. Куницын, а за ним О.Н. Петюкова строят свои типологии на основе правового статуса религиозных объединений, выделяя следующие типы:

- моноконфессиональный: теократическое государство, где признается только одна конфессия (Аревняя Русь, Ватикан);

- универсальный: в государстве функџионируют различные религиозные объединения с равным набором правам и обязанностей; 
- дифференцированный: в государстве функционируют различные ремигиозные объединения с разным набором прав и обязанностей. Внутри указанного типа авторы выделяют три вида юридического статуса религиозных объединений: религиозные объединения с государственным статусом (к примеру, Англиканская Церковь в Великобритании или ислам в Иордании); религиозное объединение с консенсуальным статусом, к примеру, в Италии, гАе действуют Аатеранские соглашения с католической церковью от 1929 г.); религиозное объединение офиџиально признано в силу своей традиџионности, в котором государство видит особую ценность Аля национального культурного наследия [16, с. 94-101; 17 , с. 19] .

Очевидно, что классификаџии М.О. Шахова и И.А. Куницына корреАируют межАу собой, поэтому преАставцяется возможным отождествить кооперационную модель с дифференцированным типом, а сепарационную модель - с универсальным, что указывает на имеющийся потенџиал Аля унификации разАичных типологий.

Еще одну трехчастную модель государственно-конфессиональных отношений предлагает коммектив авторов (С.И. Самыгин, В.И. Нечипуренко и И.Н. Полонская):

- теократическая монархия (монарх явмяется главой церкви, а государственная и духовная власти неразделимы);

- автономность церкви и государства (в демократических странах);

- принудительный атеизм, характерный для ряда стран в XX столетии) $[18$, c. 532$]$.

В.А. Кузнецов [19, с. 105-107] и А.А. Пашенцев [20, с. 19] исходят из политико-правового подхода к анализу государственно-конфессиональных отношений и также делят их на три возможных типа:

- теократическая модель, в условиях которой деятельность государства регулируется религиозными нормами и принципами, характерная дмя Ватикана, Ирана, Саудовской Аравии;

- клерикальная модель, при которой опредеменная религиозная конфессия имеет государственный статус, предоставляемый для Православной Церкви в Грещии, Амя Евангелическо-Аютеранской Церкви в Аании;

- светская модель, при которой обеспечивается равенство религиозных объединений и гарантируется равенство прав всех граждан, независимо от их религиозных взглядов (функщионирует в современных России, Франщии, США).

Подобную конџепцию применяют и некоторые европейские ученые, например Е. Венизелос [21, с. 33], который называет три типа государственно-конфессиональных отношений:

- систему однопорядковых явлений (соотносится со светской моделью);

- политократическую систему (соотносится с клерикальной моделью);

- теократическую систему (соотносится с теократической моделью).

Такое трехчастное деление, хотя и является наиболее распространенным, не может быть названо бесспорным, поскольку не исчерпывает всего многообразия форм государственно-конфессиональных отношений, а неко- 
торые из предложенных моделей трактуются неоднозначно. Так, В.Е. Чиркин не соглашается с понятием светского государства, которое предлагают названные авторы: он полагает, что наличие государственной церкви, при отсутствии притеснения иных конфессий, не означает выпадение таких стран из числа светских (например, Швеция, Великобритания и др.). Клерикальные государства, по мнению исследователя, вовсе не составцяют самостоятеАьной моАеАи, но явцяются Аишь разновиАностью теистической модели, где «государственные посты занимают священнослужители» [22, с. 53]. Противоположное мнение относительно клерикальных государств высказывал О.Е. Кутафин: «Клерикальное государство с церковью не слито. ОАнако церковь через институты, установленные законодательством, оказывает определяющее влияние на государственную политику, а школьное образование в обязательном порядке включает изучение церковных догматов. Таков, например, Иран» [23, с. 156-161]. В то жке время И.В. Понкин полагает, что словосочетание «клерикацьное государство» в современном значении приобрело искмючительно политический характер и означает использование религии и церкви Аля усиления воздействия на все сферы общественной жизни [24, с. 171].

Более современной интерпретацией предыдущих моделей представцяется классификация Е.М. Мирошниковой:

- идентификационная (государственной церкви) - государственная церковь занимает привилегированное положение во всех сферах общественной жизни. Сформировалась в эпоху СреАневековья, характерна Аля современных Великобритании, Аании, Швеции, Норвегии;

- отдемительная (сепарационная) - каждый самостоятельно определяет свои религиозные взгляды, никакое рекигиозное объединение не имеет преимушеств перед Аругим. Аанная модель реализуется во Франџии, США, Нидерландах;

- кооперационная (нейтралитета) - подлержка государством религиозного и мировоззренческого плюрализма, государство и религиозные объединения - равные партнеры. Распространена в большинстве стран Европы - Германии, Испании, Итации, Бельгии, Аюксембурге, Австрии и Аругих [25, с. 19-24].

Австрийская исследовательница К. Штекль также предлагает три основные модели церковно-государственных отношений, именуя их слеАующим образом:

- модель государственной церкви, которая участвует в определении конституџионных принципов государства (Православная церковь в Греции);

- модель, при которой государство и церковь отделены Аруг от Аруга, а все религиозные объединения равноудалены от государства (США, Франщия);

- модель избирательного сотрудничества, при которой государством Аля партнерских отношений избираются несколько религиозных объеАинений (Австрия) [26, с. 195-223].

В итоге рассмотрения трехчастных типологий государственно-конфессио- 
нальных отношений можно констатировать, что авторы по сути исследуют четыре различных модели: две из них присутствуют почти во всех классификаџиях (модель нейтральных взаимоотношений государства с религиозными объединениями и модель по типу государственной церкви); две менее попумярные модели основываются на началах государственно-конфессионацьного сотрудничества и нетерпимости государства в отношении религии.

Рассмотрим также четырехсоставные классификации. Так, четырехчастное деление предиагает М.Г. Писманик, который соотношение рекигии и ПоАитики виАит в слеАУющих формах:

- деспотическое подчинение и подавление церкви, характерное Аля стран с тоталитарным режимом;

- теократия, в условиях которой государственная и церковная вцасти слиты воеАИно;

- государственная церковь - избранная религиозная организация, пользующаяся привицегированным положением;

- правовое равенство конфессий при разделении властей [27, с. 128] .

По мнению В.Н. Протасова, четыре типа отношений государства с реАигиозными объеАинеНиями выгляАят слеАующим образом:

- светское государство (парамлельное функционирование государства и религиозных объединений);

- режим государственной церкви (привилегированный статус одного из религиозных объеАинений);

- клерикальное государство (определяющее воздействие на политику оказывает церковная иерархия);

- теократическое государство (государство и религиозное объединение фактически слиты воедино) [28, с. 450-454].

Наиболее современная типология в Аанном количественном ряду принадлежки Ф.А. фон Гейзау, профессору Аейденского университета, который выдемяет следующие четыре типа отношений государства и религиозных объеАинений:

- государства с укорененными конфессиями, которые находятся в зависимости от государственной власти и имеют привицегированный статус (Скандинавские государства, Великобритания);

- государства, где формально церковь отделена, но на практике с господствующими религиозными организациями заключены конкордаты (Австрия, Испания, Италия, Бельгия);

- государства, где законодательно закреплен принцип нейтральности по отношению к религии (Франция, Нидерланды, Германия);

- государства, в конституциях которых закрепиен принцип примата одной конфессии (Греция) [29, с. 78-79].

Определенной известностью в науке пользуется юридическая кцассификаџии В.В. Аазарева, который, полностью соглашаясь с Ф.А. фон Гейзау, Аополняет классификацию оАной нетипичной моделью - конфронтационной, при которой церковь противостоит государству, проводит антигосу- 
Аарственную кампанию, основываясь на религиозных нормах (например, Аатинская Америка 60-х годов XX в.) [30, с. 176] .

Таким образом, авторы четырехсоставных классификаций по примеру преАставителей всех предыдущих типологий соглашаются с обязательным наличием модели нейтрального положения религиозных объединений в государстве, основанном на принџипе их отдемения и равенстве религиозных объединений. Все три автора предлагают модель государственной церкви. Кроме того, предлагаются встречавшиеся в предылуших группах типологий модемь близких государственно-конфессиональных отношений (теократия, теократическое и кмерикальное государства), модель подавмения религиозных объединений государством и модель сотрудничества государства с религиозными объединениями на основе конкордатов.

Наконец, в последнюю группу классификаций можно отнести такие типы государственно-конфессиональных отношений, которые содержат пять и более их видов.

Согласно концепџии В.И. Гараджи выделяются следующие модели:

- теократическая;

- государственной церкви;

- независимое функционирование государства и церкви;

- тоталитарное государство, в котором церковь не существует в качестве самостоятельного института;

- католическая модель, наџеленная на преодоление политического кмерикализма [31, с. 159].

М.Н. Фомина также предлагает пять моделей взаимоотношений госуАарства с религиозными объединениями:

- теократическое государство, где светская и церковная власти слиты воедино (к примеру, Иран);

- государственная церковь, где определенная религиозная организация явмяется частью правительственного аппарата и выполняет некоторые светские функщии;

- церковь отделена от государства, а все религиозные объединения равны переА законом (к примеру, Франџия и США);

- церковь частично отделена от государства: при офиџиальном равенстве всех религиозных объединений переА законом одно имеет преимущественное положение (к примеру, Польша и Испания);

- квазисветское государство, где церковь запрещена и мишена юридического мица (к примеру, СССР в ХХ в.) [32, с.15-16] .

Согласно конџепции А.М. Осавелюка, можно выделить следующие модели взаимоотношений церкви и государства:

- тотальное неприятие церкви государством (история СССР после 1917 г.);

- государство опредемяет роль церкви в жизни общества (период Российской империи с петровских времен до 1917 г.);

- светское государство, где церковь существует, но не играет серьезной роли в общественной жизни (в современных Франџии, США и Германии); 
- сосуществование церкви и государства в качестве равнозначных типов организации; налеление церкви широкими полномочиями (Византийская империя и допетровская Россия);

- государственная церковь, Аоминирующая наА государственными институтами (современный Иран) [33, с. 87] .

И.В. Понкин за основу своей типологии берет критерий светскости и называет шесть моделей государственно-конфессионалыных отношений, надемяя каждую из них набором существенных признаков, которые характеризуют различные аспекты отношений государства с религиозными объединениями. Первые две из предложенных моделей могут быть отнесены к несветскому типу, остальные - к светскому:

- теократическая модель существует при полном отсутствии отделения религиозных объединений от государства (например, в Иране);

- модель секулярной квазирелигии - государство преследует задачу искоренения всякой религии и замещения ее общеобязательной идеологией (например, в нацистской Германии, КНА, $\mathrm{P}$ );

- эквипотенциальная модель внерелигиозного государства - стремление государства к максимальному изолированию религиозных объединений от государства, перевод их в плоскость частной жизни конкретных миџ (например, в КНР, Японии и Южной Корее). Автор подчеркивает, что "данная модель не может существовать в чистом виде в силу того, что невозможно Аостичь полного искАючения какого бы то ни было преАпочтения той или иной религиозной конфессии и при этом не подвергнуть верующих гражАан Аискриминации по религиозному признаку» [34, с. 187] ;

- преференциальная модель - наделение одной или нескольких религиозных организаций преимущественными правами по причине, в основном, их исторического доминирования (например, в Германии);

- контаминационная модель - религиозные объединения формально отдецены от государства в силу конституционных норм, но в реальности некоторые из них являются государственными. Так происходит в исламских и восточных государствах (к примеру, в Марокко, Таиланде, Израиле, Индии);

- идентификационная модель - государство выделяет одно или несколько религиозных объединений, но не только в связи с их историческим влиянием, как в преференциальной модеки, а учитывая современную национально-культурную и иную идентичность граждан (как, например, во Франции) [34, с. 143-204].

Аанная кцассификация весьма оригинальна, однако имеет некоторые недостатки. Так, отнесение к контаминаџионной модели столь непохожих по своим государственно-конфессионацьным отношениям стран и ислама, и будаизма, и индуизма вызывает определенные сомнения, как и отнесение этой модеми к светскому типу. Возникает вопрос о практической возможности четкого разграничения преференџиацьной и идентификаџионной моделей, поскольку в реацьности Аовольно сложно определить, выделено ми конкретное религиозное объединение по исто- 
рической причине или по национально-культурной, ибо они, как правимо, пересекаются.

Аидерами по количеству предлагаемых типов государственно-конфессиональных отношений можно назвать А.В. Кардашевского и М.Г. Тирских, в работе которых обозначено семь модемей:

- сепарационная - государство и религиозные объединения функционируют максимально независимо Аруг от Аруга, пределы их взаимодействия жестко регламентированы;

- кооптационная - один из субъектов взаимоотношений извлекает выгоду из сотрудничества, а Аругому оно безразлично;

- кооперационная - двусторонние взаимоотношения выгодны обоим субъектам и не предполагают обязательств;

- конвергенционная - взаимоотношения обоих субъектов настолько благоприятны, что их связь стремится к фактическому слиянию;

- пассивная конфронтация - взаимное влияние субъектов Аруг на Аруга нестабильно, они попеременно испытывают позитивное и негативное воздействие;

- активная конфронтация - взаимное систематическое подавление, при котором влияние государства на конфессию, и наоборот, искцючитемьно негативное;

- сегрегационная - один из субъектов подавцяет Аругого, но сам не испытывает никакого влияния [35, с. 28].

Итак, все авторы важнейших классификаций подтверждают доминирующую модель подавления госуАарством религиозных объединений и почти все заявцяют о сушествовании модели государственной церкви. Большинство авторов по традиџии вводят модель нейтрального сосуществования государства с религиозными объединениями и многие выдемяют модель привилегированного статуса одного или нескольких религиозных объединений. Как представмяется, типологии, содержащие шесть или семь модемей, сложны Амя практического применения, поскольку критерии, положенные в основу их дифференциации, не имеют четкости и однозначности, в связи с чем некоторые модели пересекаются Аруг с Аругом, вплоть до Аублирования.

В результате сравнительного обзора различных кцассификаций госуАарственно-конфессиональных отношений можно закмючить, что типологии, включающие в себя четыре и более моделей, кажутся более полными и глубокими, поскольку содержат разные комбинации характеристик, критериев и оснований. В то же время искусственное увеличение модемей с целью охватить каждое конкретное государство с его историческими и политическими особенностями приводит к утрате типологией универсальности и отрицательно сказывается на ее научной ценности.

На основе проведенного исследования классификаций предпринята попытка сформулировать авторскую типологию государственно-конфессиональных отношений, состоящую из пяти модемей: 
- конфронтационная модель: отношение государства к религиозным объединениям негативно - от максимального Аистанцирования до полного запрета религии (СССР в ХХ столетии, Япония);

- сепарационная модель: отношение государства к религиозным объединениям нейтрацьно, оба института функционируют парамлемьно и независимо (США, Франџия);

- кооперационная модель: отношение государства к религиозным объединениям положительно, налажено сотруАничество в некоторых социальных сферах Аеятельности посреАством заключения соответствующих соглашений (Германия);

- преференциальная модель: законодательно обоснованно функционирование государственной церкви (Греция);

- теократическая модель: государственная и религиозная вмасти действуют взаимосвязано и неразрывно (Иран, Великобритания).

По нашему мнению, Аанная кмассификация учитывает все основные моАели взаимоотношений государства и рекигиозных объединений и может претендовать на некоторую универсацьность. ОАнако механическое применение указанной ими мюбой Аругой типологии к современным государственно-конфессионацьным отношениям представцяется научно непродуктивным, поскольку, во-первых, данные отношения динамичны; во-вторых, они несут в себе целый комплекс исторических, правовых, политических, социальных и иных аспектов, которые сложно уложить в некую статичную

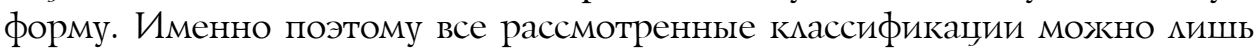
условно соотносить с конкретными государственно-конфессиональными отношениями, осторожно и ненавязчиво распредецяя и при необходимости комбинируя модели по соответствующим государствам.

\section{Библиографический список}

1. Сальгин Е.Н. Теократическое государство. М., 1999.

2. Володина Н.В. Правовые системы государственно-конфессиональных отношений. M., 2009.

3. Одинцеов М.И. Двадцатый век в российской истории: государство и религиозные организации // Вступая в третье тысячелетие: религиозная свобода в плюралистическом обществе: мат-лы междунар. конф. (Москва, 23-24 марта 1999 г.). М., 2000.

4. Потанина C.B. Некоторые аспекты взаимоотношений государства и религии за рубежом // Журнал российского права. 2001. № 4.

5. Джораева С.В. Государственно-церковные отношения в России (опыт философскоисторического анализа). М., 1997.

6. Морозова Л.А. Государство и церковь: особенности взаимоотношений // Государство и право. 1995. № 3.

7. Логинов А.В. Толерантность в государственно-конфессиональных отношениях (зарубежный опыт) // Толерантность / под общ. ред. М.П. Мчедлова. М., 2004.

8. Четверикова О.Н. Религия и политика в современной Европе. М., 2005.

9. Человеченко Т.Г. Светскость государства: актуализация проблемы в процессе ре- 
формирования государственно-конфессиональных отношений // Образование и общество. 2006. № 1(36).

10. Introduzione al diritto comparato delle religioni / a cura di S. Ferrari, A. Neri. - lugano: Europress Ftl, 2007.

11. Мировой опыт государственно-церковных отношений. М., 1998.

12. Лагода E.A. Конкордатная система как модель правового регулирования государственно-церковных отношений // Общество: политика, экономика, право. 2010. № 2.

13. Религия и закон: конституционно-правовые основы свободы совести, вероисповедания и деятельности религиозных организаций: сборник правовых актов / сост. А.О. Протопопов. М., 1996.

14. Шахов М.О. Правовые основы деятельности религиозных объединений в Российской Федерации. 2-е изд., доп. М., 2013.

15. Григоренко А.Ю. Церковно-государственные отношения в современной России и проблема религиозной свободы и нетерпимости // Вступая в третье тысячелетие: религиозная свобода в плюралистическом обществе. М., 2000.

16. Петюкова О.Н. Модели государственно-конфессиональных отношений: зарубежный опыт правового регулирования // Вестник финансовой академии. 2010. № 3.

17. Логинов А.В. Власть и вера. Государственные и религиозные институты в истории и современности. М., 2005.

18. Нечипуренко В.И., Полонская И.Н., Самыгин С.И. Религиоведение: социология и психология религии. Ростов н/Д, 1996.

19. Кузнецов В.А. Политико-правовой подход к моделям государственно-конфессиональных отношений // Вестник МИЭП. 2017. № 2 (27).

20. Пашенцев Д.А. Проблемы совершенствования отношений государства и церкви в современной России // Юридическая наука: история и современность. 2010. № 1.

21. Венизелос E. Отношения государства и церкви: взгляд через призму конституции. М., 2008.

22. Чиркин В.E. Основы сравнительного государствоведения. М., 1997.

23. Государственное право Российской Федерации: учебник / под ред. О.Е. Кутафина. М., 1996.

24. Понкин И.В. Правовые основы светскости государства и образования. М., 2003.

25. Мирошникова E.M. Кооперационная модель государственно-церковных отношений: опыт и проблемы. М., 2007.

26. Штекль К. Три модели церковно-государственных отношений в современной России // Государство, религия, церковь в России и за рубежом. 2018. № 3.

27. Религия в истории и культуре / под ред. М.Г. Писманика. М., 2000.

28. Протасов В.Н. Теория государства и права. М., 2014.

29. Красиков A.A. Религиозный фактор в европейской и российской политике (исторический аспект). М., 2000.

30. Конституционное право: учебник / под ред. В.В. Лазарева. М., 1998.

31. Гараджа В. И. Социология религии. М., 1996.

32. Фомина М. Н. Природа государственно-церковных отношений в современной России // Известия Иркутского госуниверситета. Сер.: Политология. Религиоведение. Иркутск, 2007. Вып. 1.

33. Осавелюк А.М. Церковь и государство М., 2019.

34. Понкин И.В. Правовые основы светскости государства и образования. М., 2003.

35. Кардашевский А.В. Тирских М.Г. Современные концепции государственно-конфессиональных отношений: «Сущностные» модели // Сибирский юридический вестник. 2009. № 2 (45). 